\title{
QUALITY CONTROL MEASUREMENT AND IN VITRO BIOEQUIVALENCE OF VALSARTAN AND ATENOLOL TABLETS MARKETED IN UKRAINE
}

\author{
K.Y. Peleshok \\ I. HORBACHEVSKY TERNOPIL NATIONAL MEDICAL UNIVERSITY, TERNOPIL, UKRAINE
}

Background. The urgent issue of hypertension is determined by its high population incidence, significant burden of the disease, risk of disability and impact on life expectancy. Rational combinations of drugs of different pharmacological groups in case of ineffectiveness of monotherapy to achieve the clinical effect of pharmacotherapy are clearly recommended in the world and national recommendations for diagnosis and treatment of hypertension. Therefore, innovative pharmaceutical development of a combination of antihypertensive drugs and creation of domestic drugs with antihypertensive action is an urgent task of contemporary pharmacy.

Objective. The aim of this study was to perform the quality control measurements and evaluation of dissolution tests for different brands of valsartan and atenolol tablets available in Ukraine.

Methods. The concentrations of valsartan and atenolol in samples (drug content and dissolution study) were determined by the proposed HPLC method.

Results. The results of the tests conducted for evaluation of the tablets were found to be in acceptable limits for all the selected brands. The correlation coefficient $\left(R^{2}\right)$ was 0.9991 and the regression equation was $y=61.39 x+0.3117$. It has been established that the equivalence of dissolution profiles for all recommended dissolution media is observed ( $\mathrm{pH} 1.2,4.5$, and 6.8) for the studied drugs. In all three dissolution media, the release rates of valsartan and atenolol of all dosage forms are more than $85 \%$ in $15 \mathrm{~min}$. The dissolution profile of all the selected brands was within the standard limits and was acceptable.

Conclusions. Analytical method development is an integral part of the quality control measurements and evaluation of dissolution tests. Our previously developed HPLC method is essential for quality control of a large number of samples in short time intervals. Therefore, the method developed by our group is suitable for a routine quality control analysis of any pharmaceutical preparation containing two tested drugs with the suggested chromatographic method advantages for checking quality during dissolution studies of their dosage forms.

KEYWORDS: hypertension; valsartan; atenolol; high-performance liquid chromatography; in vitro bioequivalence; dissolution.

\section{Introduction}

Valsartan (Fig. 1) is chemically described as (2S)-3-methyl-2-[pentanoyl-[[4-[2-(2H-tetrazol5-yl)phenyl]phenyl]methyl]amino]butanoic acid. Valsartan is an orally active nonpeptide triazole-derived antagonist of angiotensin (AT) II with antihypertensive properties. Valsartan selectively and competitively blocks the binding of angiotensin II to the AT1 subtype receptor in vascular smooth muscle and the adrenal gland, preventing AT II-mediated vasoconstriction, aldosterone synthesis and secretion, and renal reabsorption of sodium, and results in vasodilation, increased excretion of sodium and water, reduction of plasma volume, and reduction of blood pressure. Therefore, analytical methods for their separation and

*Corresponding author: Peleshok Kateryna, Assistant Professor, I. Horbachevsky Ternopil National Medical University, Ternopil, 46001, Ukraine.E-mail: peleshok@tdmu.edu.ua quantification in pharmaceutical formulations and inhuman plasma are needed for quality control and therapeutic drug monitoring, respectively. Several techniques have been reported in the literature for determination of valsartan individually and combination with other drug other than atenolol [1-16] in pharmaceutical dosage forms or human serum samples.<smiles>CCCCC(=O)N(Cc1ccc(-c2ccccc2-c2nn[nH]n2)cc1)C(C(=O)O)C(C)C</smiles>

Fig. 1. Chemical structure of valsartan. 
Atenolol (Fig. 2) is a synthetic isopropylaminopropanol derivative used as an antihypertensive, hypotensive and antiarrhythmic. Atenolol is chemically known as 2-[4-[2-hydroxy-3-(propan2-ylamino)propoxy]phenyl]acetamide. Atenolol acts as a peripheral, cardioselective beta blocker specific for beta-1 adrenergic receptors, without intrinsic sympathomimetic effects. It reduces exercise heart rates and delays atrioventricular conduction, with overall oxygen requirements decrease. Numerous analytical methods were reported [17-27] for determination of atenolol in bulk and combination with other drugs other than valsartan.<smiles>CC(C)NCC(O)COc1ccc(CC(N)=O)cc1</smiles>

Fig. 2. Chemical structure of atenolol.

The urgent issue of hypertension is determined by its high population incidence, significant burden of the disease, risk of disability and impact on life expectancy. Rational combinations of drugs of different pharmacological groups in case of ineffectiveness of monotherapy to achieve the clinical effect of pharmacotherapy are clearly recommended in the world and national recommendations for diagnosis and treatment of hypertension. Therefore, innovative pharmaceutical development of a combination of antihypertensive drugs and creation of domestic drugs with antihypertensive action is an urgent task of contemporary pharmacy. In the last few decades, the cost of medications is increasing a lot and it is quite challenging to afford lifelong medications for hypertension treatment. Different strategies have been planned by the healthcare systems to reduce the medication costs, improve treatment efficacy and safety and patient compliance with pharmacotherapy [28]. The results of quality control testing, such as friability, weight variation, hardness, percentage purity, and disintegration, suggests the level up to which the GMP guidelines had been followed during the manufacturing of these generic products. When the generic and the innovator brand would have comparable dissolution profile then the in vivo bioequivalence test of the generics can be waived. It was reported that fewer generics in the market were counterfeit and of inferior quality than the innovators. So, identifying these fake and suspicious generics is the prime challenge to our health department and quality control units. This research assists highlighting the pharmaceutical products which are found to be spurious, of inferior quality and dangerous to the users.

The objective of the research was to perform the quality control measurements and evaluate dissolution tests of different brands of valsartan and atenolol tablets available in Ukraine.

\section{Methods}

Valsartan (purity 99.9\%) was purchased from Jubilant Generics Limited (India); atenolol (purity $98.9 \%$ ) was purchased from SigmaAldrich (Switzerland). The methanol and acetonitrile used in experiments was HPLC gradient grade and ammonium acetate and tetramethylammonium hydroxide were of Ph.Eur.reagent grade and was purchased from Merck Darmstdat, Germany. Analytical Balance Mettler Toledo MPC227, pH-metter Metrohm 827, demineralized water by TKA Micro system, with final conductivity less than $0.05 \mu \mathrm{S} / \mathrm{cm}$, were used. IKA orbital shaker KS4000i was used for sample agitation. The nylon and regenerated cellulose RC 0.45um syringe filters were purchased from Agilent Technologies.

Dionex Ultimate 3000 UHPLC system controlled by Chromeleon version 6,80, composed of quaternary LPG pump ultimate 3000 , autosampler ultimate 3000 , ultimate 3000 column compartment, four channel UV-Vis detector ultimate 3000 RS. Shimadzu Nexera XR UPLC system with LPG Quaternary Pump LC-20AD with degasser DGU-20A5R, Autosempler SIL-20AC, PDA detector M20-A, Column Oven and Controller CBM-20A controlled by Lab Solutions version 5,97. The column Discovery C18 (4.6 mm i.d. $\times 150 \mathrm{~mm}, 5 \mu \mathrm{m})$, purchased from Sigma-Aldrich Supelco, was used.

Sample preparation

Twelve tablets of each preparation were studied to obtain statistically significant results. The tablets of different pharmaceutical manufacters with declared contents of $80 \mathrm{mg}$ valsartan and $100 \mathrm{mg}$ of atenolol were purchased from local drug store, pharmacy. The tablets were put in $100 \mathrm{~mL}$ measuring flasks and dissolved in $50 \mathrm{~mL} 50 \% \mathrm{v} / \mathrm{v}$ methanol, ultrasound crushed and treated for 2 minutes and shake 15 minutes with orbital shaker. After that measuring flasks were filled to mark of $100 \mathrm{~mL}$, the final concentrations were $1 \mathrm{mg} / \mathrm{mL}$ for atenolol and $0.8 \mathrm{mg} / \mathrm{mL}$ for valsartan. The samples 
were filtered with RC 0.45 um syringe filters and injected.

In vitro dissolution of twelve tablets containing valsartan and atenolol was performed using buffer solutions ( $\mathrm{pH} 1.2 ; 4.5 ; 6.8$ ) as the dissolution media at $50 \mathrm{rpm}$ by the USP Apparatus II. The dissolution was studied in a $900 \mathrm{~mL}$ volume of buffer solution at $37^{\circ} \mathrm{C}( \pm 0.5)$ using the paddle method. One $\mathrm{mL}$ of sample was withdrawn and replaced with fresh dissolution medium at the time intervals of $5,15,30,45$ minutes [29-32].

The concentrations of valsartan and atenolol in the samples (drug content and dissolution investigation) were determined by the suggested HPLC method.

\section{Results}

Previously, we have made method development of valsartan and atenolol in dosage forms. The optimum mobile phase composition was composed of $20 \%$ acetonitrile, $80 \%$ of $0.16 \%$ ammonium acetate and $0.2 \%$ of $1.5 \mathrm{M}$ tetramethylammonium hydroxide $(\mathrm{V} / \mathrm{V})$, pumped with $1.0 \mathrm{~mL} / \mathrm{min}$ at $30^{\circ} \mathrm{C}$ set temperature of column oven, with UV detector set to $225 \mathrm{~nm}$ and $237 \mathrm{~nm}$ wavelength. Analyses were performed by means of the column Discovery C18 (4.6 mm i.d. $\times 150 \mathrm{~mm}, 5 \mu \mathrm{m}$ ) (Fig. 3).

The results of percentage purity of all the brands are shown in Table 1. The drug content was determined to be highest for Valsartan-1 and Atenolol-4. The drug content was assessed once and compared with the calibration curve. The correlation coefficient $\left(R^{2}\right)$ was 0.9991 and the regression equation was $y=61.39 x+0.3117$.
Table 1. Drug content of different brands of valsartan and atenolol tablets

\begin{tabular}{|l|c|}
\hline \multicolumn{1}{|c|}{ Brand code } & $\begin{array}{c}\text { Drug content (\%) } \\
\mathrm{n}=20\end{array}$ \\
\hline Valsartan-1 (Innovator) & $99.82 \pm 2.24$ \\
\hline Valsartan-2 & $98.12 \pm 3.65$ \\
\hline Valsartan-3 & $99.11 \pm 2.74$ \\
\hline Valsartan-4 & $98.01 \pm 3.64$ \\
\hline Atenolol-1 (Innovator) & $99.11 \pm 1.89$ \\
\hline Atenolol-2 & $97.62 \pm 3.67$ \\
\hline Atenolol-3 & $98.55 \pm 1.95$ \\
\hline Atenolol-4 & $99.92 \pm 2.73$ \\
\hline
\end{tabular}

Dissolution test is used to determine the quality of the drug. Comparative dissolution kinetics test is used at all stages of the drugs life cycle. In the development of dosage form for comparative dissolution kinetics test allows assessing the technological correctness of techniques, and thereby increase the probability of positive results for future studies of bioequivalence. In addition to routine quality control tests, comparative dissolution tests are used to waive bioequivalence requirements (biowaivers) for lower strengths of a dosage form. Dissolution study is an important parameter used to predict the bioavailability and in vivo drug release performance. Dissolution study is very significant in determining the release of drug from different dosage forms including tablets. The active absorption of oral dosage forms depend on adequate release of drug. Comparative dissolution profiles are shown in Table 2.

The point of $15 \mathrm{~min}$ is critical and decisive. Medicine is considered very quick soluble when

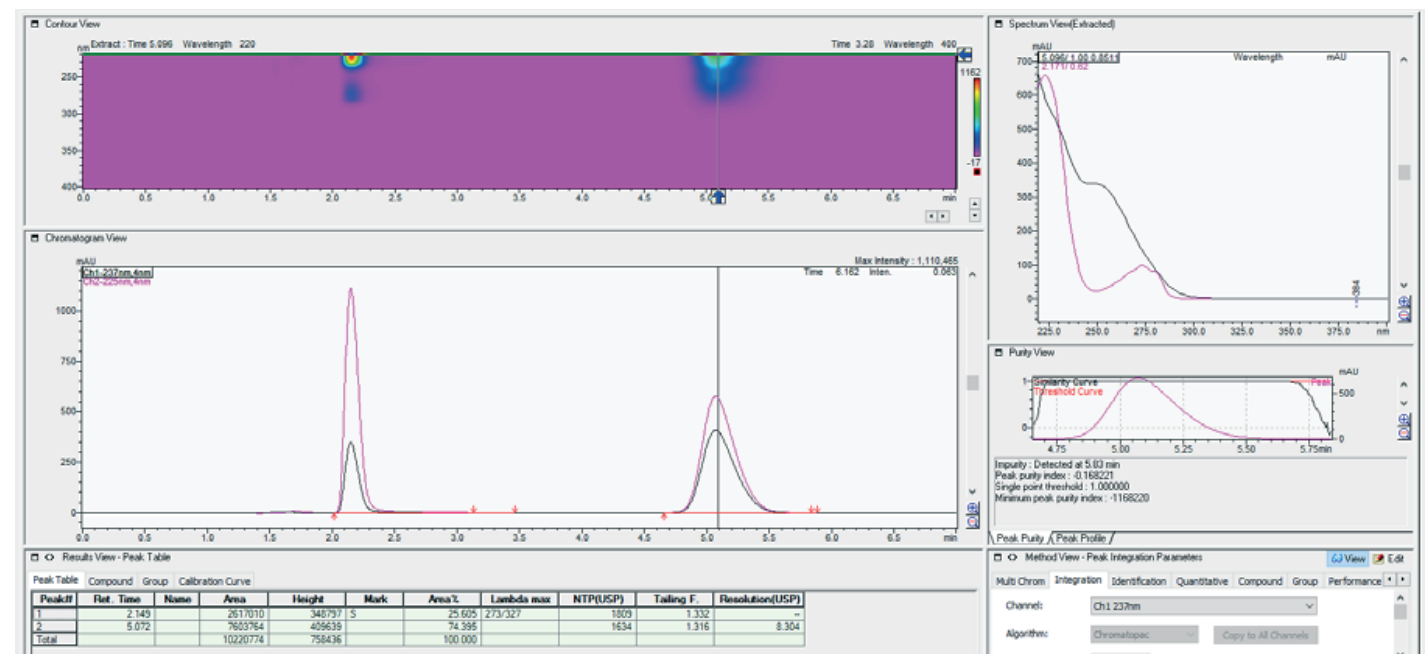

Fig. 3. Chromatogram obtained using Shimadzu Nexera XR UPLC system and mobile phase $20 \%$ acetonitrile, $80 \%$ of $0.16 \%$ ammonium acetate and $0.2 \%$ of $1.5 \mathrm{M}$ tetramethylammonium hydroxide (V/V), column Discovery C18 (4.6 mm i.d. $\times 150 \mathrm{~mm}, 5 \mu \mathrm{m})$ at 2 wavelengths $225 \mathrm{~nm}$ and $237 \mathrm{~nm}$. 
Table 2. Comparative dissolution data of valsartan and atenolol in selected brands

\begin{tabular}{|c|c|c|c|}
\hline Brand code & Medium & $\begin{array}{l}\text { \% dissolved } \\
15 \mathrm{~min}\end{array}$ & $\begin{array}{l}\% \text { dissolved } \\
30 \mathrm{~min}\end{array}$ \\
\hline \multirow[t]{3}{*}{ Valsartan-1 } & $\mathrm{pH} 1.2$ & 95.18 & 94.59 \\
\hline & $\mathrm{pH} 4.5$ & 93.84 & 93.02 \\
\hline & $\mathrm{pH} 6.8$ & 92.43 & 93.67 \\
\hline \multirow[t]{3}{*}{ Valsartan-2 } & $\mathrm{pH} 1.2$ & 89.98 & 87.37 \\
\hline & $\mathrm{pH} 4.5$ & 87.38 & 89.84 \\
\hline & $\mathrm{pH} 6.8$ & 85.19 & 86.38 \\
\hline \multirow[t]{3}{*}{ Valsartan-3 } & $\mathrm{pH} 1.2$ & 85.28 & 86.58 \\
\hline & $\mathrm{pH} 4.5$ & 87.68 & 90.01 \\
\hline & $\mathrm{pH} 6.8$ & 86.84 & 88.67 \\
\hline \multirow[t]{3}{*}{ Valsartan-4 } & $\mathrm{pH} 1.2$ & 85.89 & 85.98 \\
\hline & $\mathrm{pH} 4.5$ & 85.96 & 85.78 \\
\hline & $\mathrm{pH} 6.8$ & 86.94 & 86.05 \\
\hline \multirow[t]{3}{*}{ Atenolol-1 } & $\mathrm{pH} 1.2$ & 93.96 & 95.95 \\
\hline & $\mathrm{pH} 4.5$ & 92.56 & 93.36 \\
\hline & $\mathrm{pH} 6.8$ & 90.93 & 92.58 \\
\hline \multirow[t]{3}{*}{ Atenolol-2 } & $\mathrm{pH} 1.2$ & 91.94 & 92.67 \\
\hline & $\mathrm{pH} 4.5$ & 89.49 & 93.06 \\
\hline & $\mathrm{pH} 6.8$ & 87.56 & 90.94 \\
\hline \multirow[t]{3}{*}{ Atenolol-3 } & $\mathrm{pH} 1.2$ & 91.82 & 93.37 \\
\hline & $\mathrm{pH} 4.5$ & 90.01 & 91.65 \\
\hline & $\mathrm{pH} 6.8$ & 86.05 & 89.95 \\
\hline \multirow[t]{3}{*}{ Atenolol-4 } & $\mathrm{pH} 1.2$ & 95.96 & 96.03 \\
\hline & $\mathrm{pH} 4.5$ & 92.94 & 94.56 \\
\hline & $\mathrm{pH} 6.8$ & 91.46 & 93.14 \\
\hline
\end{tabular}

at least $85 \%$ of the active substance dissolves in 15 minutes, quickly soluble - when at least $85 \%$ of the active substance dissolves in 30 minutes. According to the obtained data, the equivalence of dissolution profiles for all recommended dissolution media has been

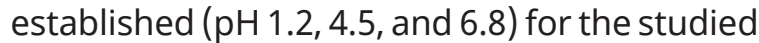
drugs. In all three dissolution media, the releases of valsartan and atenolol of all dosage forms were more than $85 \%$ in 15 min (Table 2). The dissolution profile of all the selected brands was within the standard limits and was acceptable.

\section{Conclusions}

Analytical method development is an integral part of the quality control measurements and evaluation of dissolution test. Our previously developed HPLC method was essential for quality control of a large number of samples in short time intervals. Unavailability and price of innovator brand urges patients to go for alternate options including generic brands. The selected brands were evaluated and compared with those of reference or innovator brand to assure the potential for cure of the disease. Moreover, the results of dissolution studies of all the brands were within the standard limits. This suggested that the proper GMP guidelines were followed during the manufacturing of these brands that proved a good quality. Hence, these generics may be considered to be a substitute for innovator brand in case of unavailability. Thus, all the brands selected for the study complied with the standard specifications and the definite observations on similar efficacy of these generics may be obtained after performing the in vivo studies. Therefore, the method developed by our group is suitable for the routine quality control analysis of any pharmaceutical preparation containing two tested drugs with the suggested chromatographic method with advantages for checking quality during dissolution studies of their pharmaceutical preparations.

\section{Conflict of Interests}

Authors declare no conflict of interest.

\section{Funding}

Author is grateful to the Ministry of Health of Ukraine Fund for providing scholarship for studies related to solutions for development of original combinations of antihypertensive agents, their analysis and standardization (№ 509 24.02.2020). 


\title{
ВИЗНАЧЕННЯ КОНТРОЛЮ ЯКОСТI ТА IN VITRO БІОЕКВІВАЛЕНТНОСТI ТАБЛЕТОК ВАЛСАРТАНУ ТА АТЕНОЛОЛУ РИНКУ УКРАЇНИ
}

\author{
К. Пелешок \\ ТЕРНОПІЛЬСЬКИЙ НАЦІОНАЛЬНИЙ МЕДИЧНИЙ УНІВЕРСИТЕТ ІМЕНІ І. Я. ГОРБАЧЕВСЬКОГО, \\ ТЕРНОПІЛЬ, УКРАЇНА
}

Вступ. Актуальність проблеми артеріальної гіпертензії визначається ії високою популяційною частотою, значним тягарем хвороби, ризиком інвалідизації та впливом на тривалість життя людини. у світових і вітчизняних рекомендаціях з діагностики та лікування артеріальної гіпертензії чітко рекомендовано раціональні комбінації препаратів різних фармакологічних груп при неефективності монотерапії для досягнення клінічного ефекту фармакотерапії. Тому, інноваційна фармацевтична розробка комбінації антигіпертензивних засобів та створення вітчизняних лікарських засобів антигіпертензивної дії є актуальним завданням сучасної фармації.

Мета. Здійснити контроль якості та оцінити тест розчинення різних марок таблеток валсартану та атенололу, які є представленими на ринку України.

Методи. Концентрації валсартану та атенололу у зразках (вміст в лікарських формах ma mecm розчинення) визначалися запропонованим методом ВEPX.

Результати. Результати випробувань, проведених для кількісного визначення визначення АФI таблеток, є прийнятними для всіх обраних марок. Було встановлено, що коефіцієнт кореляції $\left(R^{2}\right)$ становить 0.9991 та рівняння регресії $y=61.39 x+0.3117$. Доведено, що для досліджуваних препаратів спостерігається еквівалентність профілів розчинення для всіх рекомендованих середовищ розчинення (рн 1.2, 4.5 та 6.8). У всіх трьох середовищах розчинення вивільнення валсартану та атенололу всіх лікарських форм перевищують 85\% за 15 хв. Очінка розчинення всіх вибраних марок в межах стандартних лімітів та є прийнятною.

Висновки. Розробка аналітичної методики є невід'ємною частиною контролю якості та оцінки тесту розчинення. Розроблена нами методика ВЕРХ є важливою для контролю якості великої кількості зразків за короткі проміжки часу. Тому метод розроблений нашою групою, підходить для рутинного аналізу якості будь-якого лікарського препарату, що містить два випробувані АФІ із запропонованими перевагами хроматографічного методу для перевірки якості під час досліджень розчинення їх лікарських форм.

КЛЮЧОВІ СЛОВА: гіпертензія; валсартан; атенолол; високо ефективна рідинна хроматографія; in vitro біоеквівалентність; розчинення

Information about the author

Peleshok Kateryna - Assistant Professor, I. Horbachevsky Ternopil National Medical University, Ternopil, Ukraine.

ORCID 0000-0002-1816-6530, e-mail: peleshok@tdmu.edu.ua

\section{References}

1. Gupta KR, Wadodkar AR, Wadodkar SG. UV-Spectrophotometric methods for estimation of Valsartan in bulk and tablet dosage form. International Journal of ChemTech Research. 2010;2:98589.

2. Rao GS, Rao GV, Vardhan S, Ramachandran D. Development and validation of new UV-spectrophotometric assay method for valsartan in pure and in formulations. Journal of Chemical and Pharmaceutical Research. 2013;5:229-32.

3. Ramachandran S, Mandal BK, Navalgund SG. Simultaneous spectrophotometric determination of valsartan and ezetimibe in pharmaceuticals. Tropical Journal of Pharmaceutical Research 2011;10:809-15.

DOI: https://doi.org/10.4314/tjpr.v10i6.15

4. Nikam MB, Dhamane $\mathrm{H}$, Aligave A, Kondawar MS. Simultaneous estimation of valsartan, amlodipine besylate and hydrochlorothiazide by first order derivative UV spectrophotometric method. Int J Pharm Technol. 2010;2:642-50.

5. Selvan PS, Gowda KV, Mandal U, Solomon WDS, Pal TK. Simultaneous determination of fixed dose combination of nebivolol and valsartan in human plasma by liquid chromatographic-tandem mass 
spectrometry and its application to pharmacokinetic study. Journal of Chromatography B. 2007;858:143-50. 08.016

DOI: https://doi.org/10.1016/j.jchromb.2007.

6. Sabi-mouka EMB, Agbokponto JE, Zhang R, Li Q, Ding L. Simultaneous determination of a fixeddose combination of lercanidipine and valsartan in human plasma by LC-MS-MS: Application to a pharmacokinetic study. Journal of chromatographic science. 2016;54:1553-59.

DOI: https://doi.org/10.1093/chromsci/bmw102

7. Koseki N, Kawashita H, Hara H, Niina M, Tanaka M, Kawai R, Nagae Y, Masuda N. Development and validation of a method for quantitative determination of valsartan in human plasma by liquid chromatography-tandem mass spectrometry. Journal of pharmaceutical and biomedical analysis. 2007;43:1769-74.

DOI: https://doi.org/10.1016/j.jpba.2006.12.030

8. Tian DF, Tian XL, Tian T, Wang ZY, Mo FK. Simultaneous determination of valsartan and hydrochlorothiazide in tablets by RP-HPLC. Indian journal of pharmaceutical sciences. 2008;70:372.

DOI: https://doi.org/10.4103/0250-474X.43006

9. Chitlange SS, Bagri K, Sakarkar DM. Stability Indicating RP-HPLC Method for Simultaneous Estimation of Valsartan and Amlodipine in Capsule Formulation. Asian Journal of Research in Chemistry. 2008;1:15-18.

10. Galande VR, Baheti KG, Indraksha $S$, Dehghan $\mathrm{MH}$. Estimation of amlodipine besylate, valsartan and hydrochlorothiazide in bulk mixture and tablet by UV spectrophotometry. Indian journal of pharmaceutical sciences. 2011;74:18.

DOI: https://doi.org/10.4103/0250-474X.102538

11. Liu F, ZhangJ, XuY, GaoS, Guo Q. Simultaneous determination of hydrochlorothiazide and valsartan in human plasma by liquid chromatography/tandem mass spectrometry. Analytical Letters. 2008;41:1348-65.

DOI: https://doi.org/10.1080/00032710802119186

12. Thanusha G, Jose C, Babu G, Basavaraj KPC, Panditi VR, Sharadha C. Validated RP-HPLC method for the quantitative estimation of valsartan in bulk and pharmaceutical dosage forms. International Journal of ChemTech Research. 2010;2:1194-98.

13. Kumar PVS, Sahu M, Prasad KD, Shekhar MC. Development and validation of analytical method for the estimation of valsartan in pure and tablet dosage form by RP-HPLC method. Int. J. Res. Pharm. Chem. 2011;1:945-49.

14. Vinzuda DU, Sailor GU, Sheth NR. RP-HPLC method for determination of valsartan in tablet dosage form. International Journal of ChemTech Research. 2010;2:1461-67.

15. Kendre MD, Banerjee SK. Precise and accurate RP-HPLC method development for quantification of valsartan in tablet dosage form. International Journal of Pharmaceutical Sciences and Drug Research. 2012;4:137-39.

16. Gonzalez L, Lopez JA, Alonso RM, Jimenez RM. Fast screening method for the determination of angiotensin II receptor antagonists in human plasma by high-performance liquid chromatography with fluorimetric detection. Journal of Chromatography A. 2002;949:49-60.

DOI: https://doi.org/10.1016/S00219673(01)01496-0

17. Lalitha G, Salomi P, Ravindra RK. Development of an analytical method and its validation for the analysis of atenolol in tablet dosage form by UVSpectrophotometry. International Journal of Pharmacy and Pharmaceutical Sciences. 2013;5: 197-99.

18. Attia KA-SM, Nassar MW, Abolmagd E. Simultaneous spectrophotometric determination of amlodipine and atenolol in pharmaceutical preparations using chemometric techniques. ACAIJ. 2016;16:205-10.

19. Lalitha KV, Kiranjyothi R, Padma B. UV Spectrophotometric method development and validation for the determination of Atenolol and Losartan Potassium by Q-analysis. International Bulletin of Drug Research. 2013;3:54-62.

20. Agarwal R, Gfadnis A. Kinetic spectrophotometric determination of atenolol in perchloric acid medium. International Journal of Pharmacy and Pharmaceutical Sciences. 2012;4:350-52.

21. Basavaiah K, Chandrashekar U, NagegowdaP. Titrimetric, spectrophotometric and kinetic methods for the assay of atenolol using bromate-bromide and methyl orange. Journal of the Serbian Chemical Society. 2006;71:553-63.

DOI: https://doi.org/10.2298/JSC0605553B

22. Pai NR, Patil SS. Development and validation of liquid chromatographic method for atenolol and its related substance. Der Pharm. Sin. 2013;4:76-84.

23.Naikini P, Akula A, Ajitha A, Rao VUM. RP-HPLC method development and validation for the simultaneous estimation of amlodipine and atenolol in bulk and tablet dosage forms. International Journal of Pharmacy and Pharmaceutical Sciences. 2014;6:390-94.

24. Chaudhari V, Hussian S, Ubale M. A newer validated and stability indicating HPLC method for the estimation of Atenolol and Hydrochlorothiazide in bulk drug and dosage form. International Journal of Chemical Studies. 2013;1:93-101.

25. Belal F, Sharaf M, Aly F, Hefnawy M, Awady M. Stability-indicating HPLC Method for the Determination of Atenolol in Pharmaceutical Preparations. J Chromat Separation Techniq. 2013;4:1-7.

26. Yilmaz B, Arslan S, Determination of atenolol in human urine by gas chromatography-mass spectrometry method. Journal of chromatographic science. 2011;49:365-69.

DOI: https://doi.org/10.1093/chromsci/49.5.365

27. Tengli AR, Gurupadayya BM. Method development and validation of tablet dosage form containing losartan, atenolol and hydrochlorthiazide using internal standard by RP-HPLC. J Chromat Separation Techniq. 2013;4:1-5.

28. Gradman AH, Basile JN, Carter BL, Bakris GL. American Society of Hypertension Writing, G., Combination therapy in hypertension. Journal of the American Society of Hypertension. 2010;4:90-98.

DOI: https://doi.org/10.1016/j.jash.2010.03.001 
29. Hanson R, Gray V. Handbook on Dissolution Testing. 3rd ed. Publisher: Dissolution Technologiesgies, USA, 2004. 199 p.

30. Guidance for industry: Waiver of in vivo bioavailability and bioequivalence studies for immediaterelease solid oral dosage forms based on a Biopharmaceutics Classification System / U.S. Department of Health and Human Services, Food and Drug Administration (HHS-FDA). Center for Drug Evaluation and Research (CDER). 2017. URL: https://www.fda. gov/media/70963/download

DOI: http://academy.gmp-compliance.org/ guidemgr/files/UCM070246.PDF.
31. Popy FA, Dewan I, Parvin MN, Islam SMA. Evaluation of in vitro equivalence for tablets containing the poorly water-soluble compound atorvastatin. Dissol Technol. 2012;19(4):30-33.

DOI: https://doi.org/10.14227/DT190412P30

32. Costa P, Lobo JMS. Modeling and comparison of dissolution profiles. Eur J Pharm Sci. 2001;13:12333.

DOI: https://doi.org/10.1016/S09280987(01)00095-1

Received 27 Nov 2020; revised 21 Dec 2020; accepted 23 Dec 2020

This is open access article distributed under the Creative Commons Attribution License, which permits unrestricted use, distribution, and reproduction in any medium, provided the original work is properly cited. 